\title{
The Change Of The Auditor Towards The Big Four Auditing Firms In Mexico
}

\author{
Juan Alfonso Toscano Moctezuma \\ Institute of Social Sciences and Management \\ Autonomous University of Ciudad Juarez \\ María Antonia García Benau \\ School of Economics \\ University of Valencia
}

\begin{abstract}
In this paper, we present the results of an empirical study which analyzes the reasons why some companies with certain corporate characteristics, after having changed their external auditor, choose one of the Big Four auditing firms in Mexico. For this purpose, we have estimated a logistic regression model, using an observable sample of 972 annual reports, belonging to a total of 135 companies listed on the Mexican Stock Exchange, during the period from 2000 to 2007 . The results indicate that the reputation of the external auditor, the quality of the audit, the brand of the audit firm and the size of the external auditor, are some of the reasons why some companies with certain corporate characteristics, after having changed their external auditor, choose one of the Big Four auditing firms in Mexico, better known in the business world, such as the "Big Four".
\end{abstract}

Keywords: Change of the auditor, The reputation of the auditor, Big Four auditing in Mexico.

\section{INTRODUCTION}

The international literature indicates that the study on the analysis of the reasons that lead the audited companies to choose one of the "Big Four" after having made a change of auditor, are clearly related to the concentrated structure of the market. These studies consider that the concentrated structure of the audit services market does not arise from an arbitrary decision process, but that there are powerful economic reasons on the part of the companies that explain their behavior, as well as the structure of the audit market, to which behavior results (Zeff and Fossum, 1967; Babishi and Wyman, 1983; Francis, 1984; Simon, 1985; Baber et al., 1987; Craswell and Taylor, 1991; Bamber, et al., 1993; Beattie and Fearnley, 1994; Corona Romero et al., 1995; Simunic and Stein, 1995; Taylor, 1997; García-Benau et al., 1998; Beattie, et al., 2003; Taylor and Simon, 2003; Abidin et al., 2006 and 2007; Ballas and Fafaliou, et al., 2008; Shamharir, et al., 2008).

This means that the decisions of companies to choose a given auditor after having changed their auditor, are decisions that come from a rational model, whose explanatory variables have been submitted by accounting researchers to important studies during the last decades (Bedingfiel and Loeb, 1974; Schwartz and Menon, 1985; Simon and Francis, 1988; Beattie, 1989; Haskins and Williams, 1990; DeFond, 1992; Beattie and Fearnley, 1995; Craswell, et al., 1995; Colbert and Murray, 1998; Abbot and Susan, 2000; Culvenor and Godfrey, 2000; Balsam, et al., 2003; Branson and Breesch, 2004; Blouin, et al., 2006; Aksu, et al., 2007). 
As we justified previously; Not only is it important and necessary to know the reasons that lead to the audited companies, to choose a certain auditor after having changed his auditor; It also requires a study about the factors that can induce companies to change auditors (Barton and Roberts, 1967; Simunic, 1980; DeAngelo, 1981; Chow, 1982; Palmrose, 1986; Simunic and Stein, 1987; Croswell, 1988; Francis and Wilson, 1988; Albrecht , 1990; Sutton and Lampe, 1990; Turpen, 1990; Carcello, et al., 1992; Beattie and Fearnley, 1995; Moizer, 1997; Moizer, et al., 1998; Wallace, 1998; García-Benau et al., 2000; Copley and Douthett, 2002; Ruiz Barbadillo and Gómez Aguilar, 2003; Barton, 2005).

In the international literature, studies on auditor changes are more controversial than those on the choice of auditor, for the simple reason that after a change there is a deterioration in the relations between the auditor and his client, the audited company. This fact sometimes affects, in an important way, between the independence of the auditor and the quality of the audits carried out. In this regard, published research can be grouped into two main lines of work: I) the relationship between change and price / quality, and II) actual or potential auditor changes. In turn, these two broad lines can be framed in four basic ideas such as; 1) the relationship between change and price of the audit, 2) the relationship between change and the contracting of a quality audit, 3) the change of auditor due to a deterioration of the auditorclient relationship, and 4) the real changes or auditor potentials (Barton and Roberts, 1967; Dopuch, 1984; McConnell, 1984; Smith, 1986; Firth, 1997; Beattie and Fearnley, 1998; García Benau, et al., 1999; Hogan and Jeter, 1999; Weets, 1999; Fargher, et al., 2001; Sánchez Segura, 2003; Francis, 2004; Knechel, et al., 2008; Landsman, et al., 2008).

Now, in relation to the relationship between the change of auditor and the price of the audit, the studies published in the accounting literature consider that auditor changes are a dependent variable, while factors such as price and the quality of the audit, are considered as independent variables, which induce those changes. Thus, if after observing auditor changes, it is contrasted that the audit fees that companies pay to new auditors are lower than those paid to the previous auditor, then it can be assumed that auditor changes are motivated for reasons related to the price of the audit (Simon and Francis, 1988; Wilson and Grimlund, 1990; Johnson and Lys, 1990; Gregory and Collier, 1996).

In a different sense, other research works have contrasted if, the change of auditor is motivated by the need to obtain audits with a higher quality. For this purpose, it is verified if the auditor changes made by companies in certain scenarios demand audits with higher quality. In this sense, studies that stand out from others are those that; a) relate the change of auditor to the financial deterioration of the company, based on the hypothesis that the change of auditor is one of the measures used by the company for its reorganization (Kluger and Shields, 1991; Wilson et al., 1995; Schwartz and Soo, 1996) or b) changes in agency costs (Francis and Wilson, 1988; De Fond, 1992; Anderson et al., 1993). Finally, there are the studies that have tried to demonstrate that auditor changes occur as a result of a deterioration of the auditor-client relationship. This type of study is contrasted, if the change of auditor takes place after the issuance by the auditor of a qualified audit report, or with a denied opinion or with a negative opinion (Chow and Rice, 1982; Smith, 1986; Craswell, 1988; Krishman and Stephens, 1995; Krishman and Krishman, 1996; Krishman et al., 1996; Knap and Elikai, 1988).

The purpose of our empirical study has been to analyzes about the reasons why some companies with certain corporate characteristics, after a change of auditor towards the Big Four auditing firms in Mexico. For this matter, we investigate the relationship that exists between audited companies that have certain corporate characteristics and the direction of change of auditor towards the election of one of the Big Four auditing firms in Mexico. The 
structure of this paper is as follows: After this introduction, in the second section we have dedicated it to the review of international literature that analyzes the theoretical arguments of previous empirical studies about the reasons of the change of auditor. Next, the third section describes the methodology used. Then, in the fourth section, we present the results obtained on our empirical study about the reasons why some companies that count in their organizational structure with certain corporate characteristics, after having changed their external auditor, choose one of the Big Four auditing firms in Mexico. Finally, in the five section we present the conclusions of our empirical study.

\section{REVIEW OF THE INTERNATIONAL LITERATURE}

The international literature has been collecting an important volume of empirical studies focused on knowing the reasons why companies in certain scenarios decide to change their current external auditor. These studies have been analyzed from two conceptual approaches; 1) from a market perspective, and 2) from a contractual perspective. Thus, the change of the auditor analyzed from a market perspective is related to the functioning of the audit market, that is, with changes in the economic-financial and corporate characteristics of the companies (Palmrose, 1986; Francis and Wilson, 1988; Johnson and Lys, 1990; Menon and Williams, 1991; DeFond, 1992; Firth, 1999). The other conceptual approach to auditor change is analyzed from the perspective of the contractual relationship that links the client company with the auditor and which is defined by the environment in which the audit offer is developed and the greater or lesser negotiation power of both parties being, therefore, factors of a strategic nature (De Angelo, 1982; Chow and Rice, 1982; Schwartz, 1982; McConnell, 1984; Kinney and McDaniel, 1989; Magee and Tseng, 1990; Nalebuff, 1991; Dye, 1991; Krishnan, 1994).

\section{The change of auditor from a market perspective}

The international literature highlights the conceptual approach that analyzes auditor changes from the market perspective, that is; It starts with the premise that the audit must be conceived as a technological function that must be efficient for the organization of the audited companies, so it will be considerations of an economic nature that will explain the contractual relationship between the audited companies and their auditors. In this sense, Johnson and Lys (1990) suggest that companies and auditors are motivated by market competition to align, which will depend both on the characteristics of the audit demand, that is, on the specific attributes required of the audit services, as well as the characteristics of the offer made by the auditor. Therefore, this conceptual approach tries to understand auditor changes, based on the existence of a heterogeneous demand for audit services, that is, not all companies demand the same attributes or with the same intensity.

Thus, the characteristics of the demand that explain this heterogeneity will depend on various factors such as; the complexity of the audit, the nature of the company's activity, the level of informational asymmetry, the capital structure, the level of agency costs, etc. (Jensen and Meckling, 1976; Francis and Wilson, 1988; Johnson and Lys, 1990; DeFond, 1992; Whisenant and Sankaraguruswamy, 2000). Based on this reasoning, a change in the environment of the activities of the companies can alter the demand requirements of the audit service, a situation that could cause a deterioration, in terms of the competitive advantage of the current auditor.

For example, a rapid growth of companies can cause a substantial change in; the volume of transactions, the complexity of accounting information, the level of company diversification, the geographical dispersion of activities, the complexity of control systems and their financing needs. Similar reasoning can be presented, when a certain company decreases or contracts its level of activity, in this case it may happen that said company derived from its new economic- 
financial situation will require an audit service more in line with its new needs that can be seen reflected perhaps in the contracting of a less specialized service or with a lower level of credibility, in order to reduce the fees of the audit. All these factors, according to the accounting research published in the international literature, can weaken the economies previously acquired by the company auditor. For the simple reason that, once an audit firm has structured itself in a certain way to offer its audit services based on a certain level of specialization and differentiation, then it may happen that it will suddenly be enormously complex to alter the attributes of its service offer, mainly due to the organizational inflexibility of the audit process. The new requirements of the audit service demand by the audited companies can make the current auditor inefficient. so the change of auditor would be explained by the need of the audited company to find another auditor that offers the service with a certain level of quality different from the one currently received, that is, the audited company needs to hire a new auditor who will offer the service according to your new business requirements (Ruiz Barbadillo and Nieves Gómez Aguilar, 2003).

Among the factors that from this market perspective have been analyzed as inducers of the change of auditor we can mention; the growth of the company, the takeovers of companies, the agency costs of the company, the variations in the capital structure of the company and the costs of the audit (Williams, 1988; Firth, 1999; Watts and Zimmerman, 1983; 1986).

The growth of the company. This factor can be considered as an indicator of the variation of the geographical dispersion level and the complexity of the accounting information that the company processes. In this sense, it has been considered that companies undergoing a growth process decide to seek new auditors more in line with their new structure and organization (Palmrose, 1986; Francis and Wilson, 1988; Williams, 1988).

Absorption of companies. The acquisition of another company, according to the accountant researchers Anderson et al., (1993) and Firth (1999) is an event in the life of the company that could cause auditor changes. This is due to the interest of the absorbed company to change the auditor of the absorbing company because in this way it can reinforce the economies of scale that can be obtained from the joint audit of the entire business group.

The agency costs of the company. Accounting researchers distinguish two types of agency costs, depending on whether they are relationships between management and shareholders "capital agency costs", or between company and debtors "debt agency cost". The reasoning behind the relationship between the agency costs of the company and the change of auditor is that, the higher the agency costs of the company, since the accounting information aims to reduce them, higher then, the requirements for the company to present high quality accounting information (Palmrose, 1984; Piot, 2001). In this way, the level reached by the agency costs of the companies will determine a differentiated quality demand for the audit that can explain the auditor changes. The representative variables of the company's agency costs, which accounting researchers have been using in their empirical works, are: management's ownership participation, the existence of incentives for senior executives based on the results, the degree of dispersion of ownership, financial leverage, and size of the audited company (Palmrose, 1986; Francis and Wilson, 1988).

The variation in agency costs has also been analyzed as a possible inducer of the auditor change. For this, the variables that have been used would represent the variation of those previously indicated in a more or less long period of time. According to the results obtained by the accounting investigators Francis and Wilson (1988), De Fond (1992) and Haskins and Williams (1990), the variation of agency costs turns out to be related to auditor changes, even 
these accounting researchers consider that The variables that represent the variation in agency costs are more explanatory than those that refer simply to levels of agency costs.

Variations in the capital structure of the company. Multiple studies that show that there are incentives to change the auditor before facing changes in the capital structure of the company, derived from the issuance of new debt or capital, to acquire the advantage of the experience or reputation of a new auditor. In effect, the reputation or experience of the auditor may be particularly valuable to investors as a means of reducing the information costs of securities to be issued (Titman and Trueman, 1986; Healy and Lys, 1986; Simunic and Stein, 1987; Balvers et al., 1988; Tomczyk, 1996; Bédard et al., 2000; Menon and Williams, 2001; Beatty and Fearnley, 2002; Copley and Douthett, 2002).

\section{The change of auditor from a contractual perspective}

The other line of research to interpret auditor changes focuses on the perception of the audit as a commercial contract in which the company freely chooses the auditor and where the possible existence of disagreements between the auditor and the company can lead to the auditor The company decides to make a change of auditor (Chow and Rice, 1982; De Angelo, 1982; Schwartz, 1982; McConnell, 1984; Schwartz and Menon, 1985; Craswell, 1988, Krishnan, 1994; Francis and Krishnan, 1999; Lennox, 2000). This implies that the audit of the financial statements of the company can be considered as a negotiation process between the company and the auditor (Antle and Nalebuff, 1991; Dye, 1991). Under this perspective, the change of auditor could be motivated by the opportunistic behavior of the manager of the company to achieve its objectives with respect to the accounting information (De Angelo, 1982).

In this sense, the accounting literature shows how companies tend to manipulate or omit accounting information or perform liberal interpretations in the application of accounting principles by making discretionary accrual adjustments that increase profits when they show a weak financial situation (Kluger and Shields, 1989; Dhaliwal et al., 1993; DeFond and Jiambalvo, 1993; DeFond and Subramanyam, 1998).

What the accounting researchers intend with this type of analysis is, definitively, the knowledge on the supply side, on the type of behavior and the strategic behavior of the audit firms, and on the other hand, that is, From the point of view of demand, accounting investigators have also been interested in analyzing the factors that determine the election of the auditor and the change of auditor in any case, both decisions made by the audited companies (Vives, 1990; García-Benau, et al., 1998). In a market such as that of audit services, where there is a strong informational asymmetry between bidders and claimants and, therefore, an additional difficulty to assess the quality of the service offered, the brand name is an essential attribute on which the differentiation of the auditor is based. However, the quality of work of the auditor is not observable externally, the accounting research has been using various indirect sub-rogations that allow to differentiate the quality of the auditors. One of these is based on the consideration of two groups of auditors in attention to the brand name, distinguishing the "Big Four" as those with a differentiated and recognized brand name, and the rest of the suppliers in the market as those that lack a brand name (Simunic and Stein, 1987; and Craswell et al., 1995). If we look at the definition of reputation provided by DeFond et al., (2002), as a skill to get new customers while retaining existing ones, it is then that the "Big Four" are the most reputable and the highest quality. This means that the factors that explain the change in the auditor become relevant to the extent that they indirectly reveal the reasons that condition the companies that after a change of auditor decide to select a signature of the "Big Four" (DeAngelo, 1981; Teoh and Wong, 1993; Arruñada, 2000; García-Benau et al., 2000; Robertson, 2002; Barton, 2005). Around what we have written before; we want at this 
moment to make a brief description of different works that have been aimed at contrasting the reasons that induce companies to make auditor changes. In order to propose a criterion for the management of published research, we present it in terms of two broad lines of work, the synthesis of which is shown in Table 1.

Table 1. Previous studies about the change of the auditor

\begin{tabular}{ll} 
Reasons for audit change & \multicolumn{1}{c}{ Basic Idea } \\
& Relationship between \\
& auditor change \\
& and \\
& price/quality
\end{tabular}

Relationship between auditor change

and

price/quality
Quality Audits

Reasons that lead to the change of Auditor

or

that would lead to change
Most Important Research Papers

Simon and Francis, 1988

Johnson and Lys, 1990

Turpen, 1990

Buttenworth and Houghton, 1995

Gregory and Collier, 1996

Schwartz and Menon, 1985

Francis and Wilson, 1988

Haskins and Williams, 1990

DeFond, 1992

Andersen et al., 1993

Wilson et al., 1995

Ruíz B. and Gómez A., 2003

Chow and Rice, 1982

Smith, 1986

Craswell, 1988

Krishnan and Stephens, 1995

Krishnan et al., 1996

Ruíz B. and Gómez A., 2003

Sánchez Segura, 2003

Burton and Roberts, 1967

Carpenter and Strawser, 1971

Bedingfield and Loeb, 1974

Eichenseher and Shields, 1983

Beattie and Fearnley, 1995

García-Benau et al., 2000

First, as can be seen in table 1, we place those works that start with effective changes in the auditor and in which it is a question of verifying the reasons that motivate the change. The experimental design of these empirical studies considers auditor changes observed as a dependent variable, while factors such as price and quality are conceived by accounting research as the independent variables that induce such auditor changes. So then, if after observing auditor changes we contrasted that the audit fees paid by the companies to the new auditors are lower than those paid to the former auditor, then it can be shown that, the changes are motivated by related reasons with the prices of the audit. Relevant studies within this line of research are those of Simon and Francis (1988), Johnson and Lys (1990), Turpen (1990), Butterworth and Houghton (1995) and Gregory and Collier (1996). On the contrary, other empirical research works try to contrast if the change of auditor is motivated by the need to obtain audits of higher quality. For this purpose, it is verified whether said changes take place in certain scenarios that may imply the demand for higher quality audits (Robertson, 2002; Stein, 2006). As well; Research studies can be highlighted, such as those by Schwartz and Menon (1985), Haskins and Williams (1990), Kluger and Shields (1991) and Wilson et al., (1995), which relate auditor change with financial deterioration of the company, based on the hypothesis that the change of auditor is one of the strategies used by the company for its reorganization; or changes in agency costs associated with the change of auditor (Francis and Wilson, 1988; De Fond, 1992; Anderson et al., 1993; Ruiz and Gomez, 2003). Finally, exist a series of empirical studies that have tried to demonstrate that auditor changes occur as a result 
of a deterioration of the auditor-client relationship. In them, it is contrasted if the change of auditor takes place after the issuance of a qualified audit report, or with an adverse opinion or with a denied opinion (Chow and Rice, 1982; Smith, 1986; Craswell, 1988; Deberg et al., 1991; Knapp, 1991; Krishnan and Stephens, 1995; Schwartz and Soo, 1996; Krishnan et al., 1996; Ruiz Barbadillo and Gomez Aguilar, 2003; Sanchez Segura, 2003).

On these empirical studies, it should be noted, as we did in previous paragraphs, that these are based on an initial definition of certain contexts, which are; a) those that determine that there is a change in the demand for quality of the audit required by the company, or b) that the auditor change occurs because there is a deterioration in the relations between auditor and client, and subsequently, through of the analysis of the change of auditor, then, to be able to induce, on the reason that explains it. In this way, we must emphasize that the a priori judgments that this type of experimental studies incurs, may imply that certain variables not subject to control may be due more to chance than causality (Jones and Raghunandan, 1998). This methodological limitation explains the existence of another line of empirical works in which the audited companies themselves, through questionnaires, are those who express the factors that have induced or induced a change in the auditor (Beattie and Fearnley, 1995). In this case, we consider it necessary to make a description of certain contexts to analyze the change of auditor, which also allows us to analyze together the reasons that refer to prices and quality. On the other hand, it should be noted that it is not necessary to have observed changes in the auditor, information that is difficult to obtain. In addition, when information is available on auditor changes, it is noted that these are not numerous enough to make a strict hypothesis test. Empirical studies of this type are those of Barton and Roberts (1967), Carpenter and Strawser (1971), Bedingfield and Loeb (1974), Eichenseher and Shields (1986) and Beattie and Fearnley (1995). Based on the perceptions of the people interviewed, these authors, mentioned above, in their studies have contrasted through their empirical studies the existence in audited companies of a number of aspects, such as; changes in management, need to have alternative services to audit, obtaining new debt, dissatisfaction with the work offered, mergers, etc., which become the reasons that suggest or advise making a change of auditor.

\section{Reasons for the change of auditor towards the Big 4}

So far, we have presented the theoretical arguments on which accounting research is based to conceptually justify that the concentrated structure of the audit market can be explained by the heterogeneous demand of the audit service, concluding that the change of auditor oriented towards the choice of a reputed auditor, is a determining factor for certain companies that demand that the audit has a quality superior to the minimum quality legally required, that provides credibility to its financial statements and, in addition, that is perceptible by thirdparty users. However, as highlighted in the accounting literature, the decision of the company to change its auditor is conditioned by the high costs involved in absorbing it when it is proposed to make an auditor change aimed at hiring an auditor specialized in granting a level of superior quality in the market, which implies assuming that there are plenty of reasons that justify the choice of a firm of the "Big Four" group, such as; the size and complexity of the audited company, the need to transfer to the markets accounting information endorsed by reputable auditors and the desire to mitigate existing agency conflicts. Thus, hiring a quality auditor after a change of auditor can bring significant advantages, and therefore companies with certain corporate characteristics consider reputation as a key factor in the choice of a "Big Four". First, because the choice of a reputed auditor gives credibility to the accounting information of the companies and therefore the investor's confidence in the integrity of the financial statements of the companies (Teoh and Wong, 1993; Krishnamurthy et al., 2002; Eisenberg and Macey, 2003; García-Benau, et al., 2004). Secondly; because the hiring of a quality auditor helps to mitigate agency conflicts and reduce contract costs, and thus, in 
companies with significant debt, it also monitors the debt (Chow, 1982; Nichols and Smith, 1983; Weets, 1999; Arruñada, 2000; Woo and Koh, 2001; Pittman and Fortín, 2005; Broye and Weill, 2008). In third place; because the hiring of a reputed auditor is related to the level of shareholding of international investors in listed companies, which they interpret in terms of providing credibility to financial information. Because the choice of a reputable and large-sized quality auditor like the "Big Four" guarantees greater coverage of services and additionally (Nichols and Smith, 1983; Sucher et al., 1998; Firth, 2002; Antle et al., 2004; Francis et al., 2005; Monterrey and Sánchez, 2008).

\section{Formulation of hypotheses}

\section{METHODOLOGY}

The change of auditor towards one of the Big Four auditing firms could mitigate the existing agency conflicts in the companies, by favoring a perception of greater credibility of the accounting information. These conflicts of agency in the companies can be presented between minority shareholders and majority shareholders, derived in the probable case that there could be transfers of economic profits, from those minority shareholders to the majority shareholders. Also, in companies in which their assets are financed with financial debt, agency conflicts can arise from the financial creditors towards the company's shareholders. In the same way; Agency conflicts in companies may arise among foreign investors, derived from the probable case that there are transfers of economic profits from those to the managers. In this type of scenario, the agency theory predicts the selection of quality and reputation auditors where agency conflicts are more severe (Jensen and Meckling, 1976; Palmrose, 1984; Piot, 2001).

The first of the hypotheses that we will test in our investigation is related to the effect that the level of importance on share ownership may cause the change of auditor to be oriented or directed towards the election of a reputed auditor. According to Shleifer and Vishny (1986) and Firth and Smith (1992), holders of significant stock packages are likely to demand a superior quality audit, as an additional guarantee of trust and credibility of the company's accounting information. Consequently, the first of our hypotheses is as follows:

H1Change auditor: After a change of auditor, the companies with majority shareholders have more incentives to contract the services of the audit to one of the "Big Four" auditing firms in Mexico.

The second hypothesis to be contrasted is that related to one of the causes of most known agency conflicts; the indebtedness for the external financing of the companies. In effect, high levels of debt are associated with significant risk profiles, generating then incentives to make decisions that favor the interests of shareholders to the detriment of financial creditors (De Fond, 1992; Firth and Smith, 1992), or engaging in accounting practices aimed at artificially exhibiting high financial capacity (DeFond and Jiambalvo, 1994; Sweeney, 1994). In these situations, Simunic and Stein (1987) and Francis and Wilson (1988), observed in their respective empirical works a negative association between the level of debt of the company and the selection of one firm of the "Big Four". The reason, according to these researchers, could be that the large audit firms could be avoiding the review of companies with a high level of leverage due to their higher risk when it comes to the audit. Therefore, our second hypothesis is as follows:

H2Change auditor: After a change of auditor, less indebted companies have greater incentives to contract the services of the audit to one of the "Big Four" auditing firms in Mexico.

The third hypothesis related to agency conflicts and the credibility of financial information, is based on the assumption that companies with foreign investors may be heavily influenced to 
hire one of the "Big Four". This is because these large firms of international audits are considered more reputable by the users of the accounting information, and especially by foreign investors, because these users consider that reputable auditors add credibility and reliability to the financial statements of the companies they audit (Citron and Manalis, 2001). Therefore, for our third hypothesis we expect a positive association between the presence in the companies of foreign investors and the direction of the change of auditor towards a reputed auditor, as follows:

H3Change Auditor: After a change of auditor, companies with foreign investors have greater incentives to contract the services of the audit to one of the "Big Four" auditing firms in Mexico.

The fourth hypothesis related to the costs of agency, according to Healy and Lys (1986), Johnson and Lys (1986), Simunic and Stein (1987), Francis and Wilson (1988), Firth and Smith (1992) and Abbott and Parker (2000), they assume that there is a positive association between the size of the audited companies and the selection of the highest quality audit firms, because they perceive the size of the audited company as a fundamental indicator of their level of agency costs. In the Greek audit market, accounting researchers Citron and Manalis (2001) found that the size of the client company is positively related to the selection of the "Big Six". In addition, according to Barton (2005), the largest audited companies can receive greater attention from the large international audit firms. We expect in our fourth hypothesis a positive association between the size of the companies audited and the direction of the change of auditor towards the selection of a quality auditor:

H4Change Auditor: After a change of auditor, larger companies have greater incentives to contract the services of the audit to one of the "Big Four" auditing firms in Mexico.

The fifth and last of our hypotheses to consider in our empirical study about the change of auditor towards one of the "Big Four", supposes that the companies that require advice will seek the services of a large auditor, because he guarantees them a greater coverage of additional services such as consulting, taxes, legal services, etc. (Deberg et al., 1991; Firth, 2002; Antle et al., 2004; Barton, 2005). Thus, for our fifth hypothesis we expect a positive relationship between the contracting of additional services by companies and the direction of the change of auditor towards the contract of a reputed auditor, as follows:

H5Change Auditor: After a change of auditor, companies that contract additional services to the audit have more incentives to choose one of the "Big Four" auditing firms in Mexico.

Finally, our study will include as control variables, the sectors of economic activity of the companies based on the classification of the Mexican Stock Exchange: (1) Commerce, (2) Communications and Transportation, (3) Construction, (4) Industry Extractive, (5) Services, (6) Transformation and (7) Miscellaneous. The authors Willekens et al., (2004), point out that it is necessary to control the effects of economic sectors because agency conflicts can differ among them. Consequently, we expect a positive association between the economic activity sector of the company and the direction of the change of auditor towards a reputed auditor.

\section{Model estimate}

In order to analyze the reasons why some companies with certain corporate characteristics, after having changed their external auditor, choose one of the "Big Four" auditing firms in Mexico, we have estimated the following logistic regression model:

$$
\begin{gathered}
\text { DCAUD } i=\beta 0+\beta 1 \text { ACCSMAYS }+\beta 2 \text { ENDEUD }+\beta 3 \text { INVEXTR }+\beta 4 \text { LOGACT }+\beta 5 \text { SERVAD + } \\
\Sigma \beta i S E C T O R i+\varepsilon i
\end{gathered}
$$




\section{Where:}

The dependent variable DCAUD is a dichotomous variable that has a value equal to $\mathbf{1}$ if after a change of auditor, the companies in our sample used in this research, choose one of the Big Four auditing firms in Mexico, better known as the "Big Four" [Ernst \& Young (EY), Deloitte, KPMG and PricewaterhouseCoopers ( $\mathrm{PwC})]$ and if after a change of auditor, the election of the new auditor by the companies is towards another firm that is not one of the "Big Four", then it will have a value equal to $\mathbf{0}$. In this regard, the international literature indicates that the brand is one of the indicators of the differentiation in the quality of auditors in the audit market, distinguishing the "Big Four" because they have a differentiated brand name and a recognized reputation. In contrast, the rest of the firms participating in this audit market do not have a brand name (Simunic and Stein, 1987; Craswell et al., 1995; DeFond et al., 2002; Ireland and Lennox, 2002).

The independent variables that explain the reasons why companies, whit certain corporate characteristics after having made a change of auditor, choose one of the "Big Four" auditing firms in Mexico, are the following:

\section{a) Majority shareholders}

As an approximation of the presence of majority shareholders in the companies, we have defined the explanatory variable ACCSMAYS, which was measured according to the percentage of shares of the capital stock of the companies held by the main internal shareholders (Vafeas, 1999; Bédard et al., 2004). The information related to this independent variable has been obtained through the annual reports of the companies in the sample, which can be found in the database published on the website of the Mexican Stock Exchange.

\section{b) Financial debt of the company}

The second independent variable ENDEUD refers to the financial debt of the companies, as a result of dividing the total liabilities between the total assets of the company at the end of the year (Eichenseher and Shields, 1989; DeFond, 1992; Firth and Smith, 1992; Abbot and Parker, 2000). The financial information for the determination of the financial reason of the debt level of the companies was obtained through the observation of the financial statements of the companies in the sample, contained in the annual reports of the companies and which are published in the database of the website of the Mexican Stock Exchange.

\section{c) Foreign investors}

As an approximation of foreign investors in companies, the third independent INVEXTR variable has been defined, dummy variable that will take the value $\mathbf{1}$, if the company has a presence of foreign investors with shareholding, and $\mathbf{0}$ otherwise. For this variable, we have based on the research published by Citron and Manalis (2001) that studied the choice of the auditor in Greece. The results obtained in that research highlight the existence of a positive association between the choice of Big Four and the level of participation of international investors in listed companies. This information was obtained from the annual reports of the listed companies in the sample, that are in the database published on the website of the Mexican Stock Exchange.

\section{d) Size}

As regards the measure corresponding to the fourth independent variable LOGACT, it represents the size of the audited company and is defined by the neperian logarithm of the total assets of the company at the end of the year. In this respect, the literature gathers diverse works through which this surrogate has been used, such as those of Palmrose (1984), Francis and Wilson (1988), Williams (1988) and Eichenseher and Shields (1989). Likewise, and in agreement with Citron and Manalis (2001), they showed that the size of the client company is 
positively related to the selection of the Big Six. The total assets of the companies in the sample, expressed in thousands of Mexican pesos, has been obtained through the financial statements in the annual reports of the companies listed on the Mexican capital market published in the web page of the Mexican Stock Exchange.

\section{e) Additional services}

As an approximation of the additional services hired by the companies, the fifth independent variable SERVAD has been defined, dummy variable that will take the value 1, if the company, in addition to contracting the audit services, additionally contracts with the same selected auditor, others additional professional services, such as; consulting, tax advice, legal advice, etc., and will take the value of $\mathbf{0}$ otherwise. In this regard, the results of Firth (2002) and Antle et al. (2004) highlight that certain companies with advisory needs would tend to hire a large auditor, because it guarantees a greater coverage of services and, in addition, the reduction of expenses that for the company may imply the fact that the auditor jointly determines the audit and consulting fees, as it is possible to overlap joint costs. The information on this variable has been obtained by observing the annual reports of the companies in the sample, contained in the database published on the Mexican Stock Exchange.

\section{f) Sector}

Finally, as an approximation of the SECTOR of economic activity of the audited company, seven dummy control variables have been defined. The sectors are the following: commerce (COM), communications and transport (CYT), construction (CONSTR), extractive industry (INDEXTR), services (SERV), transformation (TRANSF), and several (VAR). In all cases it will take the value 1 , if the company belongs to the selected sector and 0 otherwise. This information has been obtained from the website of the Mexican Stock Exchange.

\section{Description of the sample}

For the realization of our empirical study on the reasons that lead to Mexican companies with certain corporate characteristics, that after a change of auditor, they decide to choose a firm of the Big 4, it has been considered a time horizon of eight years, which includes the period from 2000 to 2007, both years inclusive. For this, we started from an observable sample of 972 annual reports belonging to a total of 135 non-financial companies that are listed on the Mexican Stock Exchange, whose economic activity of these companies corresponds to one of the following sectors; 1) trade, 2) construction, 3) extractive industry, 4) services, 5) transformation, 6) several, and 7) communications and transport. Of the 972 company-year observations, we have obtained a final sample of 99 observations in which companies after a change of auditor decided to hire a new auditor. The financial information that integrates the analyzed sample described in the previous section, was obtained directly from the database that the Mexican Stock Exchange publishes on its website (http://www.bmv.com.mx). The summary of the sample data is shown in Table 2, below:

Table 2. Description of the sample

\begin{tabular}{lcccccccccc}
\multicolumn{1}{c}{ Description } & $\mathbf{2 0 0 0}$ & $\mathbf{2 0 0 1}$ & $\mathbf{2 0 0 2}$ & $\mathbf{2 0 0 3}$ & $\mathbf{2 0 0 4}$ & $\mathbf{2 0 0 5}$ & $\mathbf{2 0 0 6}$ & $\mathbf{2 0 0 7}$ & Total & $\mathbf{\%}$ \\
Audit changes & 7 & 7 & 25 & 19 & 14 & 11 & 9 & 7 & $\mathbf{9 9}$ & $\mathbf{1 0 , 2 \%}$ \\
$\begin{array}{l}\text { Total } \\
\text { observations }\end{array}$ & 108 & 113 & 117 & 120 & 124 & 134 & 131 & 125 & $\mathbf{9 7 2}$ & $\mathbf{1 0 0 \%}$
\end{tabular}

As can be seen in Table 2, of the total of the 972 observations that make up our sample, there were only 99 auditor changes made by the companies audited during the period from 2000 to 2007. It can also be observed that, the largest number of auditor changes made by companies 
in the analyzed sample was presented in 2002, with 25 effective auditor changes. One of the main reasons was the reordering of the Mexican audit market as a result of the disappearance of the international firm Arthur Andersen after the Enron scandal in 2002.

With regard to the evolution of auditor changes made by companies, we can see in table 2 that, as of 2002, the tendency of Mexican companies to change auditors has been to the low. Also, that the total percentage of auditor changes made by Mexican companies for the period analyzed is equivalent to $10.2 \%$ of the total sample used. This total percentage of auditor changes of $10.2 \%$ achieved for the Mexican case, allows us to highlight that the tendency to make auditor changes by Mexican companies in the analyzed sample is far above the data provided by others. empirical studies.

In this sense, Chow and Rice (1982) in their study obtained a percentage of change of 4.4\% in their analyzed sample, Krishnan and Stephens (1995) reached 6.5\% and in Krishnan et al. to the. (1996) a $6.2 \%$ rate of auditor changes is observed. In this regard, it is also necessary to highlight with respect to our empirical study that the percentage of auditor changes reached for 2007 is $5.6 \%$ and compared with the studies in the specialized accounting literature. The results obtained are shown in Table 3, next:

Table 3. Number of auditor changes in Mexico, according to the sample

\begin{tabular}{|c|c|c|c|c|c|c|c|c|c|c|}
\hline Concepto & 2000 & 2001 & 2002 & 2003 & 2004 & 2005 & 2006 & 2007 & Total & $\%$ \\
\hline $\begin{array}{l}\text { Auditor changes toward one of } \\
\text { the Big Four auditing firm }\end{array}$ & 6 & 5 & 24 & 12 & 6 & 10 & 9 & 6 & $\underline{78}$ & $\underline{79 \%}$ \\
\hline $\begin{array}{l}\text { Auditor changes toward another } \\
\text { audit firm, different from one of } \\
\text { the Big Four auditing firm }\end{array}$ & 1 & 2 & 1 & 7 & 8 & 1 & 0 & 1 & 21 & $21 \%$ \\
\hline $\begin{array}{l}\text { Total of Audit changes made by } \\
\text { Mexican companies }\end{array}$ & 7 & 7 & 25 & 19 & 14 & 11 & 9 & 7 & 99 & $100 \%$ \\
\hline
\end{tabular}

As shown in table 3, of the 99 effective auditor changes that make up our final sample, we observed 78 events in which companies after an auditor change decided to hire an audit firm of the "Big Four", which represents 79\% of the total of the sample, for only 21 changes of auditor oriented to select a signature of the rest of the auditing firms. These data reveal the tendency of the companies in the sample to preferentially hire an audit firm of the "Big Four". In the table 4 we show in more detail the direction of the auditor change, as follows: 


\begin{tabular}{|c|c|c|c|c|c|c|c|c|c|}
\hline Year & $\begin{array}{l}\text { Big Four } \\
\text { to } \\
\text { Big Four } \\
\text { Number } \\
\text { of } \\
\text { changes }\end{array}$ & $\%$ & $\begin{array}{l}\text { Other Au } \\
\text { Firms } \\
\text { to } \\
\text { Big Four } \\
\text { Number } \\
\text { of } \\
\text { changes }\end{array}$ & $\%$ & $\begin{array}{l}\text { Big Four } \\
\text { to } \\
\text { Other Au } \\
\text { Firms } \\
\text { Number } \\
\text { of } \\
\text { changes }\end{array}$ & ng & $\begin{array}{l}\text { Other A } \\
\text { Firms to } \\
\text { Other A } \\
\text { Firms } \\
\text { Number } \\
\text { of } \\
\text { changes }\end{array}$ & $\begin{array}{l}\text { ing } \\
\text { ing }\end{array}$ & $\begin{array}{l}\text { Total } \\
\text { Auditor } \\
\text { changes } \\
\text { made } \\
\text { by } \\
\text { Compani } \\
\text { es }\end{array}$ \\
\hline 2000 & 6 & $86 \%$ & 0 & $0 \%$ & 0 & $0 \%$ & 1 & $14 \%$ & 7 \\
\hline 2001 & 4 & $57 \%$ & 1 & $14 \%$ & 0 & $0 \%$ & 2 & $29 \%$ & 7 \\
\hline 2002 & 22 & $88 \%$ & 2 & $8 \%$ & 1 & $4 \%$ & 0 & $0 \%$ & 25 \\
\hline 2003 & 11 & $58 \%$ & 1 & $5 \%$ & 3 & $16 \%$ & 4 & $21 \%$ & 19 \\
\hline 2004 & 5 & $36 \%$ & 1 & $7 \%$ & 5 & $36 \%$ & 3 & $21 \%$ & 14 \\
\hline 2005 & 9 & $82 \%$ & 1 & $9 \%$ & 0 & $0 \%$ & 1 & $9 \%$ & 11 \\
\hline 2006 & 6 & $67 \%$ & 3 & $33 \%$ & 0 & $0 \%$ & 0 & $0 \%$ & 9 \\
\hline 2007 & 4 & $57 \%$ & 2 & $29 \%$ & 1 & $14 \%$ & 0 & $0 \%$ & 7 \\
\hline Total & 67 & $68 \%$ & 11 & $11 \%$ & 10 & $10 \%$ & 11 & $11 \%$ & 99 \\
\hline
\end{tabular}

In Table 4, we can see that the percentage reached in terms of auditor changes between the "Big Four" is equivalent to $68.0 \%$ and that is represented by 67 auditor changes made by the companies of the sample analyzed during the period from 2000 to 2007. Also we can see in Table 4, that in the year of 2002, Mexican companies made 22 auditor changes, from one of the "Big Four" auditing firms to another audit firm of the "Big Four", equivalent to 88\% of the total auditor changes that occurred for that particular year. Also, we noted that most of these changes were basically due to the fact that the "Big Four" absorbed a large part of the client portfolio of the audit firm Arthur Andersen, after its disappearance from the world audit markets and in particular from the market of Mexican audit after the accounting scandal of Enron in the year of 2002. Continuing with our analysis of the data in Table 4, we observed 11 changes of auditor made by the companies of our sample used that go in the direction of the rest of the audit firms other than the "Big Four" for the entire study period, also highlighting the 10 auditor changes that go in the opposite direction, that is, the "Big Four" to the rest of the audit firms other than the "Big Four". Finally, we observe in Table 4, regarding the 11 auditor changes that occurred between the rest of the audit firms other than the Big Four, for the period of our study.

\section{Descriptive analysis}

\section{EMPIRICAL RESULTS}

Before proceeding to perform the logistic regression of the model, then, in Table 5, we present some descriptive statistics of the continuous independent variables, as follows: 
Table 5. Descriptive statistics of independent variables

$\begin{array}{cccccc}\text { Variables } & \text { N } & \text { Minimum } & \text { Maximum } & \text { Mean } & \begin{array}{c}\text { Standard } \\ \text { deviation }\end{array} \\ \text { ACCSMAYS } & 99 & .33 & .99 & .7845 & .16522 \\ \text { ENDEUD } & 99 & .05 & 1.59 & .5763 & .25772 \\ \text { INVEXTR } & 99 & 0 & 1 & .36 & .4830 \\ \text { LOGACT } & 99 & 12.06 & 21.01 & 15.5277 & 1.77586 \\ \text { SERVAD } & 99 & 0 & 1 & .42 & .497 \\ \text { COM } & 99 & 0 & 1 & .15 & .360 \\ \text { CYT } & 99 & 0 & 1 & .11 & .316 \\ \text { CONSTR } & 99 & 0 & 1 & .10 & .303 \\ & 99 & 0 & 1 & .07 & .258 \\ \text { INDEXTR } & 99 & 0 & 1 & .10 & .303 \\ \text { SERV } & 99 & 0 & 1 & .40 & .493 \\ \text { TRANSF } & 99 & 0 & 1 & .10 & .303 \\ \text { VAR } & 99 & & & & \end{array}$

In Table 5, some descriptive statistics that characterize the data of the sample are collected. With regard to the variable ACCSMAYS representative of the degree of concentration of ownership of the company in favor of the majority shareholders, it exhibits an average value of $78.45 \%$, although with a notable dispersion. This explains the high concentration of social capital held by the main shareholders, mainly represented by families that control these companies. As for the variable ENDEUD, it includes an average ratio of 0.5763, which means that the debt of the companies in the sample is at a level close to the average level. However, we also note that the maximum debt of these companies is in the ratio of 1.59 and on the contrary is in a minimum ratio equivalent to 05 of the debt of these companies. Regarding the INVEXTR variable, it can be observed that $36 \%$ of the companies in the sample have foreign investors, while the variable LOGACT that is deflated by the logarithm of the total assets, presents an average value of 15.5277 and a relevant dispersion. This means that the average size of the companies measured by the total assets is about 5,554 million Mexican pesos equivalent to 306.7 million euros, although without noting the maximum level of the size of these companies around 1,330 thousand dollars. million pesos equivalent to about 73,451 million euros. For its part, the variable SERVAD highlights that $42 \%$ of the companies in the sample hire additional services from their auditor in turn. Finally, as regards the sectors of economic activity of the companies in the sample, we can highlight the transformation sector (TRANSF) as the one that is mostly represented by the companies in the sample with $40 \%$ and, on the contrary, the sector of the mining industry (INDEXTR) with only about $7 \%$ of the total companies in the sample.

\section{Univariate analysis}

Before moving on to the hypothesis, in Table 6, we present a univariate analysis of the difference in means, segmenting the total sample between the companies audited by the "Big Four" and the companies audited by the other auditing firms included. For this purpose, we verified whether there are significant differences between the behaviors of both samples, using therefore the nonparametric test of the Mann-Whitney $U$ for the continuous variables and the Chi-square test for the dichotomous categorical variables. 


\begin{tabular}{|c|c|c|c|c|}
\hline Variables & $\begin{array}{c}\text { Companies audited } \\
\text { by the } \\
\text { BIG FOUR } \\
(\mathrm{N}=78)\end{array}$ & $\begin{array}{c}\text { Companies audited } \\
\text { by NOT BIG FOUR } \\
(\mathrm{N}=21)\end{array}$ & $\begin{array}{l}\text { Difference } \\
\text { of } \\
\text { Means }\end{array}$ & $\begin{array}{l}\text { Univariate } \\
\text { test } \\
\text { (significant) }\end{array}$ \\
\hline ACCSMAYS & .8174 & .6624 & 0.15505 & $423.500(\mathrm{p}=0.001)^{*}$ \\
\hline ENDEUD & .5558 & .6524 & -0.09661 & $\begin{array}{c}692.000 \\
(p=0.277)\end{array}$ \\
\hline LOGACT & 15.8103 & 14.4781 & 1.33216 & $452.500(\mathrm{p}=0.002)^{*}$ \\
\hline INVEXTR & .45 & .05 & .40 & $\begin{array}{c}7.364 \\
(p=0.007)^{*}\end{array}$ \\
\hline SERVAD & .50 & .14 & .36 & $\begin{array}{c}2.273 \\
(p=0.132)\end{array}$ \\
\hline $\mathrm{COM}$ & .15 & .14 & .01 & $\begin{array}{c}48.091 \\
(p=0.000)^{*}\end{array}$ \\
\hline CYT & .08 & .24 & -.16 & $\begin{array}{c}59.889 \\
(p=0.000)^{*}\end{array}$ \\
\hline CONSTR & .10 & .10 & .00 & $\begin{array}{c}63.040 \\
(p=0.000)^{*}\end{array}$ \\
\hline INDEXTR & .09 & .00 & .09 & $\begin{array}{c}72.980 \\
(p=0.000)^{*}\end{array}$ \\
\hline SERV & .12 & .05 & .07 & $\begin{array}{c}63.040 \\
(p=0.000)^{*}\end{array}$ \\
\hline TRANSF & .38 & .48 & -.10 & $\begin{array}{c}3.646 \\
(p=0.056)^{*}\end{array}$ \\
\hline VAR & .13 & .00 & .13 & $\begin{array}{c}63.040 \\
(p=0.000)^{*}\end{array}$ \\
\hline
\end{tabular}

According to the data collected in table 6, it can be observed in terms of independent quantitative variables, that both the variable ACCSMAYS "representative of the percentage of shares in favor of the majority shareholders of the company", and the variable LOGACT "representative of the size of the company measured by the logarithm of its total assets ", show a statistically different behavior, that is, that the difference of means of these two variables are significantly different between the companies audited by the big international companies "Big Four" and the companies audited by other auditing firms at the 5\% significance level.

Likewise, we observe that these variables show the expected values, that is to say, the companies in the sample that select the big international companies "Big Four" as their independent auditor show a greater percentage of shares of social capital in favor of the main shareholders and also that they are the largest in terms of their business size.

On the other hand, the variable ENDEUD "representative of the level of indebtedness of the audited company" at the univariate level does not show a statistically significant difference of the means at the level of 5\%. Regarding the average values of the debt, it is observed that the level of debt of the companies audited by the big international companies "Big Four" is lower compared to the level of indebtedness of the companies that were audited by other auditing firms. 
As regards independent categorical variables, we observe in Table 6, that the INVEXTR variable "representative of the presence of foreign investors in the audited company" at the univariate level shows a different behavior, that is, the difference in means is significantly different between the companies that choose the big international companies "Big Four" and those that choose other auditing firms, at a $5 \%$ level of significance.

We also observe that this variable does show the expected values, that is, the presence of foreign investors is greater in the Mexican companies that select the big international firms "Big Four" as their external auditor than the companies that choose other auditing firms. as its independent auditor.

On the other hand, regarding the variable SERVAD «representative of the presence of additional services contracted to the selected auditor by the audited company» we observe that the differences in means are not significant at $5 \%$ level of significance, although it does show the Expected values, that is, the companies that are audited by the "Big Four" are the ones that contract more frequently additional services to their auditors in turn with respect to the companies that are audited by other auditing firms.

Finally, regarding the control variables corresponding to the activity sectors of the audited companies, we observe that the mean differences for all these variables are statistically significant, at $5 \%$ level of significance, although in terms of the expected values, These, show mixed results.

To evaluate if there is multi collinearity, given that the number of observations of the sample used to test the hypotheses is quite small, we have calculated the Spearman correlation coefficients of the independent variables. In this way, we can analyze with a better perspective the results reported by the estimation of the proposed logistic regression model. In table 7, we offer the results of the correlation matrix of the sample of companies: 
Table 7. Spearman correlations among the explanatory variables of the model

\begin{tabular}{|c|c|c|c|c|c|c|c|c|c|c|c|c|}
\hline Variables & $\begin{array}{l}\text { ACCS M } \\
\text { AYS }\end{array}$ & $\begin{array}{l}\text { END } \\
\text { EU }\end{array}$ & $\begin{array}{l}\text { INV } \\
\text { EXTR }\end{array}$ & $\begin{array}{l}\text { LOG } \\
\text { ACT }\end{array}$ & $\begin{array}{l}\text { SERV } \\
\text { AD }\end{array}$ & COM & CYT & $\begin{array}{l}\text { CONS } \\
\text { TR }\end{array}$ & $\begin{array}{l}\text { IND } \\
\text { EXTR }\end{array}$ & $\begin{array}{l}\text { SERV } \\
\text { AD }\end{array}$ & $\begin{array}{l}\text { TRA } \\
\text { NSF }\end{array}$ & $\begin{array}{l}\text { VA } \\
\text { RIOS }\end{array}$ \\
\hline $\begin{array}{l}\text { ACCS } \\
\text { MAYS }\end{array}$ & 1 & & & & & & & & & & & \\
\hline ENDEUD & .119 & 1 & & & & & & & & & & \\
\hline INVEXTR & -.046 & .113 & 1 & & & & & & & & & \\
\hline LOGACT & .129 & $.240^{*}$ & .143 & 1 & & & & & & & & \\
\hline SERVAD & .109 & .109 & .116 & $.279^{* *}$ & 1 & & & & & & & \\
\hline COM & .003 & .004 & -.085 & $-.213^{*}$ & -.021 & 1 & & & & & & \\
\hline CYT & -.036 & .156 & .067 & .150 & -.043 & -.149 & 1 & & & & & \\
\hline CONSTR & -.140 & .006 & .095 & -.148 & -.152 & -.142 & -.119 & 1 & & & & \\
\hline INDEXTR & .141 & .185 & -.127 & $.328^{* *}$ & $.242^{*}$ & -.117 & -.098 & -.092 & 1 & & & \\
\hline SERV & -.012 & -.179 & .165 & -.035 & .119 & -.048 & -.119 & -.112 & -.092 & 1 & & \\
\hline TRANSF & .021 & $.231^{*}$ & -.023 & -.186 & -.082 & $-.348^{* *}$ & $-.291^{* *}$ & $-.276^{* *}$ & $-.227^{*}$ & -.139 & 1 & \\
\hline VARIOS & -.036 & .195 & .025 & $.341^{* *}$ & .051 & -.142 & -.119 & -.112 & -.092 & -.001 & $-.276^{* *}$ & 1 \\
\hline
\end{tabular}

**The correlation is significant at the 0.01 level (bilateral). *Correlation is significant at level 0,05 (bilateral) $\mathrm{N}=112$

From the results presented in Table 7, it follows that the correlation between the pairs of all independent variables is smaller, since none of the Spearman correlation coefficients is sufficiently high ( $>0.60$ ) to cause significant problems multi collinearity (Citron and Manalis, 2001, Pittman and Fortin, 2005), also considering that the objective of our proposed model is to identify the determinants of the choice of the Big 4 assuming that there are variables that are interrelated between them and not in isolation.

\section{Multivariate analysis}

Once the univariate results have been analyzed and in order to analyze how all the variables proposed for the testing of the hypotheses act together, first we have proceeded to estimate the logistic regression model described above (Jovell, 1962). The results obtained are presented below in the table 8, as follows: 
Table 8. Results about proposed model to analyze auditor change towards the Big Four in Mexico

DCAUD $i=\beta 0+\beta 1$ ACCSMAYS + $\beta 2$ ENDEUD + $\beta 3$ INVEXTR + $\beta 4$ LOGACT + $\beta 5$ SERVAD + $\Sigma \beta i S E C T O R i$ $+\varepsilon i$

\begin{tabular}{|c|c|c|c|c|}
\hline \multirow[t]{2}{*}{ Variables } & \multirow{2}{*}{$\begin{array}{l}\text { Expected } \\
\text { Sing }\end{array}$} & \multicolumn{3}{|c|}{$\begin{array}{c}\text { Model 1 } \\
\text { (with all the proposed variables) }\end{array}$} \\
\hline & & $\begin{array}{l}\text { Coefficient } \\
\text { Model }\end{array}$ & $\begin{array}{l}\text { Test } \\
\text { Wald }\end{array}$ & $\begin{array}{r}\text { Statisti } \\
\text { Significan }\end{array}$ \\
\hline Constant & & -4.765 & 1.348 & .24 \\
\hline ACCSMAYS & + & 9.390 & 11.640 & .00 \\
\hline ENDEUD & - & -6.471 & 9.013 & .00 \\
\hline INVEXTR & + & -4.718 & 10.144 & .00 \\
\hline LOGACT & + & 0.544 & 4.373 & .03 \\
\hline SERVAD & + & -2.058 & 4.265 & .03 \\
\hline $\mathrm{COM}$ & + & -0.014 & 0.000 & .98 \\
\hline CYT & + & 2.741 & 4.787 & .02 \\
\hline CONSTR & + & 3.313 & 2.089 & .1 \\
\hline INDEXTR & + & 18.336 & 0.000 & .9 \\
\hline SERV & + & -1.329 & 0.741 & .3 \\
\hline TRANSF & + & -0.042 & 0.002 & .9 \\
\hline VAR & + & 20.115 & 0.000 & .90 \\
\hline
\end{tabular}

Chi-Cuadrado $=53.770(\mathrm{p}=0.000) 6$ gl.

Pseudo $\mathrm{R}^{2}=0.650$

Porcentaje de clasificación correcta $=89.9 \%$

Table 8, presents the results of the logistic regression model 1 "that includes all the proposed variables" and which was initially constructed to identify the factors that explain the choice of the auditor by the Mexican companies in the sample. Thus, we can observe the result of the Chi-Square test, which shows the goodness of the model in general that reaches a value of 53,770 (for 6 degrees of freedom), so the null hypothesis of non-existence of statistical relationship, it can be rejected. Also, we observe that the value for the Pseudo $\mathrm{R}^{2}$ is $65 \%$, which means that the explanatory power of the model is high enough to be considered acceptable. The correct classification percentage is $89.9 \%$ of the observations and the Hosmer and Lemeshow test has revealed that there are no statistical differences between the estimated values and the real values (Chi-square $=5.377, \mathrm{p}=0.717$ ). . Thus, in its entirety, the results of the logistic regression obtained for model 1 reveal the goodness of the adjustment made. With regard to the explanatory variables ACCSPPLS, INVEXTR and LOGACT, the results obtained in the estimation of model 1 are consistent with those obtained in the univariate analysis, all the coefficients of these explanatory variables and with the expected signs being statistically significant.

Regarding the variables ENDEUD and SERVAD, the results of the estimation of model 1 are different from those we had found at univariate level, because at the multivariate level these two variables show a statistically significant behavior, however at the univariate level they were the opposite. As regards the signs expected for these two variables, the results of model 1 are consistent with those achieved at the univariate level. Finally, regarding the control variables, only the CYT variable acquires statistical meaning and with the expected sign, unlike the results obtained in the univariate analysis in which all the control variables were statistically significant and with the expected signs.

Given that the logistic regression of the estimation of model 1 contained all the independent variables, and in order to be able to determine the most parsimonious model, that is, the model 
that offers the most robust results that allows us to explain the concentration of the Mexican audit market, from the point of view of the audited companies, and in particular about some of the determinants of the choice of the "Big Four" in Mexico, the data of the sample have been returned again but now using only the six explanatory variables that were statistically significant in the previous model 1 . The results obtained from the logistic regression of the estimation of model 2 are shown in the following Table 9:

Table 9. Results of the model that explains the change of the auditor towards the Big Four in

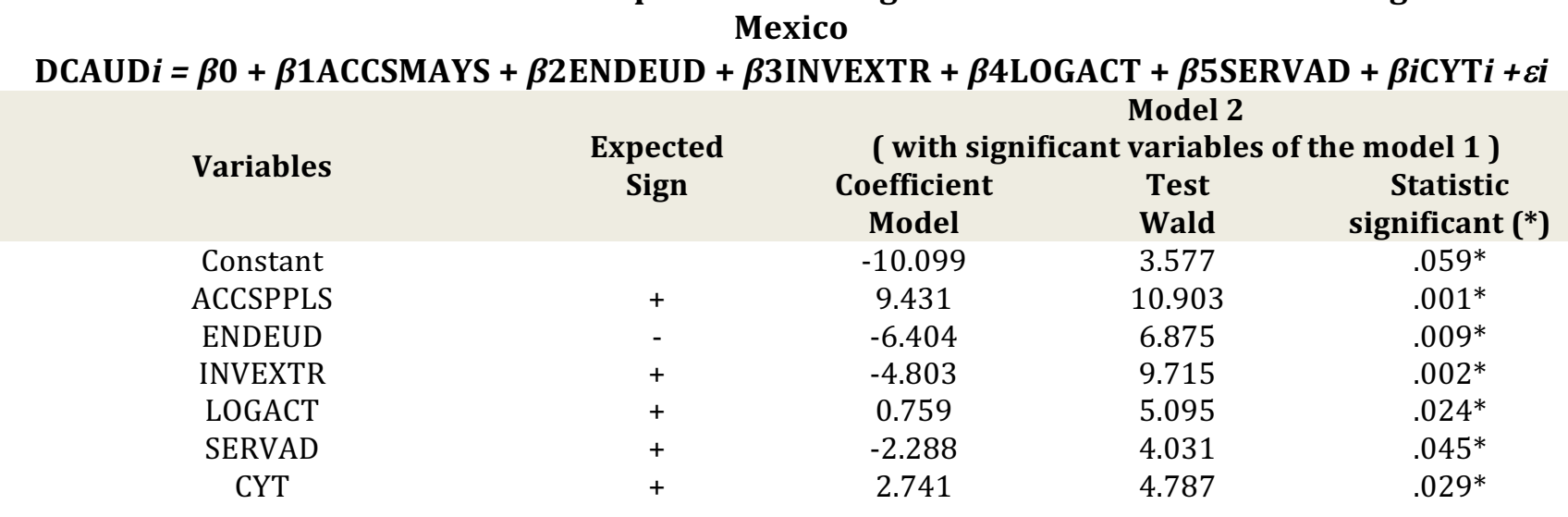

Chi-Cuadrado $=59.340(\mathrm{p}=0,000) 6$ gl.

Pseudo $\mathrm{R}^{2}=0.700$

Porcentaje de clasificación correcta $=91.9 \%$

As shown in table 9, model 2 is statistically significant, while offering a greater explanatory capacity than the previous model 1 as indicated by $70 \%$ of the Pseudo $\mathrm{R}^{2}$ as a measure of the degree of adjustment of the model. Therefore, these results confirm the validity of the explanatory variables that were statistically significant in the previous model 1 . Also, it can be observed in Table 9, that the Chi-Square statistical of model 2, reaches a value of 59.5340 (for 6 degrees of freedom), meaning that the null hypothesis of the non-existence of statistical relationship can be rejected. Another measure of the goodness of the adjustment is determined by the correct classification percentage provided by the model estimated model 2 represented by $91.9 \%$ of the total observations compared to $89.9 \%$ achieved in the previous model 1 . Likewise, the performance of the Hosmer and Lemeshow test revealed that there are no statistical differences between the estimated values and the real values (Chi-square $=1.769, \mathrm{p}$ $=0.987$ ).

Regarding the meaning of the coefficients or estimated parameters of the variables in model 2, we observe in Table 9, that all the coefficients resulted with the expected sign, except for the variables INVEXTR and SERVAD. However, these two variables, as well as the other variables included in model 2, all without exception, were statistically significant, as shown by the Wald statistics obtained, all of them high, among them those referring to the variables ACCSMAYS and INVEXTR. with the highest Wald coefficients $=10,903$ and 9.715 respectively. Thus, we observe in Table 6.15 that all the variables included in model 2 have been statistically significant $(\mathrm{p} \leq 0.05)$. For the results obtained in the present model 2 , we can confirm the explanatory capacity of all the variables included in it at the multivariate level.

This means that:

a) The companies audited in Mexico, whose capital stock is highly concentrated in favor of the internal principal shareholders "investors with a significant shareholding", are more likely to choose a reputed auditor and with quality audit from the group of the "Big Four", after having made a change of auditor. 
b) The companies audited in Mexico with a lower level of debt, are more likely to choose a reputed auditor and with quality audit from the group of the "Big Four", after having made a change of auditor.

c) The companies audited in Mexico with the presence of foreign investors, have more reasons to choose a reputed auditor and with quality audit from the group of the "Big Four", after having made a change of auditor.

d) The companies audited in Mexico, with the largest business size, are more likely to choose a reputed auditor and with quality audit from the group of the "Big Four", after having made a change of auditor.

e) The companies audited in Mexico, that need to contract additional services are more likely to choose a reputed auditor and with quality audit from the group of the "Big Four", after having made a change of auditor.

f) The companies audited in Mexico whose economic activity belongs to the communications and transport sector according to the classification made by the Mexican Stock Exchange, are more likely to choose a reputed auditor and quality audit, from the group of the "Big Four", after having made a change of auditor.

\section{CONCLUSIONS}

In summary, based on the results obtained in model 2, it can be affirmed that the change of auditor towards the "Big Four" auditing firms in Mexico, is based on the next corporate characteristics "agency relations" of the audited companies; a) the presence of internal shareholders with significant holdings, b) the level of indebtedness, c) the presence of foreign investors, d) the size of the business, e) the requirement for additional services, and f) the requirement of specialization in the communications and transport sector.

Therefore, we can conclude that the model 2 is that offers the most robust results on some of the reasons for the change of auditor towards the "Big Four" in Mexico, by companies with certain corporate characteristics, is the following:

\section{DCAUDi $=-10,099+9,431$ ACCSMAYS + (-6,404) ENDEUD + (-4,803) INVEXTR + 0,759 LOGACT + $(-2,288)$ SERVAD + 2,741 CYT $i+\varepsilon i$}

Where, the reasons why the companies after having a change of auditor in Mexico choose one of the auditing firms of the "Big 4" in Mexico, is conditioned by the following corporate characteristics of the audited companies, such as; 1 ) the presence of major shareholders with significant holdings, 2) the level of the debt, 3) the presence of foreign investors, 4) the size of the business, 5) the requirement for additional services and 6) the auditor's specialization in the sector of communications and transport.

Finally, it is necessary to emphasize, about the possible limitations that this empirical work can present. First, we consider that the results should be interpreted with caution, since it is possible that some variables that could better explain model 2 were omitted so much to determine the reasons that explain the change of auditor towards the "Big Four" in Mexico. Secondly, the sample size used in the present work could have been very small compared to what could be obtained in the future. 


\section{BIBLIOGRAPHIC REFERENCES}

ABIDIN, S. ; BEATTIE, V. AND GOODACRE, A. (2006) : "Audit Market Concentration and Auditor Choice in the UK", University of Sterling, Working paper, pp. 1-15

ABIDIN, S. ; BEATTIE, V. AND GOODACRE, A. (2007) : "An Analysis of UK Audit Market Concentration and Fee Rates: Pre and Post Andersen Demise (1998-2003)”, University of Sterling, Working paper.

ABBOTT, L. AND PARKER, S. (2000) : “Auditor selection and audit comittee characteristics", Auditing : A Jouornal of Practice and Theory, Vol. 19 (2), pp. 47-66.

ABBOT, L.J. AND SUSAN, P. (2000) : “Auditor selection and audit committe characteristics”. Auditing : A Journal of Practice and Theory Fall, pp. 47-67.

ABDEL-KHALIK, A. (1993) : "Why do private companies demand auditing? A case for organizational loss of control", Journal of Accounting, Auditing and Finance, Vol. 8(1), pp. 31-52.

ALBRETCH, W. (1990) : The determinants of the market reaction to an announcement of a change in auditor, PhD thesis, Virginia Polytechnic Institue \& State University.

AKSU, M. ; ONDER, T. AND SAATCIOGLU, K. (2007) : “Auditor Selection, Client Firm Characteristics, and Corporate Governance: Evidence from an Emerging”, Working Paper available at Faculty of Management Sabanci University, pp. $1-44$.

ANDERSON, D.; STOKES, D. AND ZIMMER, I. (1993) : “Corporate Takeovers and Auditors Switching ", Auditing: A journal of Practice \& Theory, Vol. 12, No. 1, p. 65-73.

ANTLE, R. ; AND NALEBUFF, B. (1991) : “Conservatism and Auditor-Client Negotiations”, Journal of Accounting Research, 29 (supplement), p. 31-59.

ANTLE, R.; GORDON, E.A.; NARAYANAMORTHY, G. AND ZHOU, L. (2004) : "The joint determination of audit fees, non-audit fees, and abnormal accruals”, Working paper, Yale University.

ARRUÑADA, B. (2000): "Audit quality: Attributes, private safeguards and the role of regulation", The European Accounting Review, 9, pp. 205-224.

BABER W.; BROOKS, E. AND RICKS, W. (1987): “An Empirical Investigation of the Market for Audit Services in the Public Sector”, Journal of Accounting Research, Vol. 25 No. 2, Autumn, pp. 293-305.

BALSAM, S.; KRISHNAN, J. AND YANG, J. (2003): “Auditor industry specialization and earnings quality, Auditing: A Journal of Practice and Theory, vol. 22(3), pp. 71-97.

BALVERS, R. J.; MCDONALD, B.; AND MILLER, R. E. (1988): “Underpricing of new issues and the choice of auditor as a signal of investment banker reputation", The Accounting Review, 58(4), pp. 605-622.

BALLAS, A. AND FAFALIOU I. (2008): "Market shares and concentration in the EU auditing industry: The Effects of Andersen's Demise”, International Advances in Economic Research, 14(4) pp. 485-497.

BAMBER, M.; BAMBER, L. AND SCHODERBEK, M. (1993): “Audit Structure and other Determinants of Audit Report Lag: An Empirical Analysis", Auditing, Vol. 12, No. 1, pp. 1-23.

BARTON, J.C. AND ROBERTS, W. (1967): “A study of auditor changes”. The Journal of Accountancy, volume 123(4), pp. 66-69.

BARTON, J. (2005): “Who Cares About Auditor Reputation?” Contemporary Accounting Research, 22(3), pp. 549586.

BAVISHI, V. AND WYMAN, G. (1983): Who Audits the World: Trends in the World-wide Auditing Profession, Center for Transnational Accounting and Financial Research: University of Connecticut.

BEATTIE, R. (1989): “Auditor Reputation and the Pricing of Initial Public Offerings”, The Accounting Review, No. 4, p. 693-707.

BEATTIE, V. AND FEARNLEY, S. (1994): "The Changing Structure of the Market for Audit Services in the UK-A Descriptive Study”. British Accounting Review, Vol. 26, December, pp. 301-322.

BEATTIE, V. AND FEARNLEY, S. (1995): "The importance of audit firm characteristics and the drivers of auditor change in UK listed companies", Accounting and Business Research, 25, Winter, pp. 227-239

BEATTIE, V. AND FEARNLEY, S. (1998): “Audit market competition: auditor changes and the impact of tendering”, British Accounting Review, 30, pp. 261-290.

BEATTIE, V. AND FEARNLEY, S. (2002): Auditor independence and non-audit services: A literature review, London: Institute of Chartered Accountants in England and Wales. 
BEATTIE, V.; GOODACRE A. AND FEARNLEY S. (2003): "And then there were four: A study of UK audit market concentration - causes, consequences and the scope for market adjustment", Journal of Financial Regulation and Compliance, 11 (3) pp. 250-265.

BÉDARD, J.; COULOMBE, D.; AND COURTEAU, L. (2000): “Demand and Supply of Auditing in IPOs: An Empirical Analysis of the Quebec Market", Document of work.

BÉDARD, J; CHTOUROU, S.M. AND COURTEAU, L. (2004): "The effect of Audit Committee expertise, independence, and activity on aggressive earnings management, Auditing: A Journal of Practice \& Theory, 23, pp. 13-35.

BEDINGFIELD, J.P. AND LOEB, S.E. (1974): “Auditor Changes-an Examination”, The Journal of Accountancy, March, pp. 66-69.

BLOUIN, J.; GREIN, B. AND ROUNTREE, B. (2006): “An Analysis of Forced Auditor Change: The Case of Former Arthur Andersen Clients", Accounting Review, Forthcoming, Available at SSRN: http://ssrn.com/abstract=934413.

BRANSON, J. AND BREESCH, D. (2004): "Referral as a determining factor for changing auditors in the Belgian auditing market: An empirical study", The International Journal of Accounting, 39, pp. 307-326.

BROYE, G. AND WEILL, L. (2008): “Does leverage influence auditor choice? A cross-country analysis”, Applied Financial Economics, vol. 18, pp. 715-731.

BURTON, J. AND ROBERTS, W. (1967): “A Study of Auditor Changes", Journal of Accountancy, April, pp. 31-36. BUTTERWORTH, S. AND HOUGHTON, K. (1995): “Auditor Switching: The Pricing of Audit Services", Journal of Business Finance \& Accounting, Vol. 22, No. 3, pp. 323-344.

CARCELLO, J. HERMANSON, R. AND MCGRATH, N. (1992): “Audit quality attributes: The perceptions of audit partners, preparers and financial statement users, Auditing: A Journal of Practice \& Theory, 11(1), pp. 1-15.

CARPENTER, C.G. AND STRAWSER, R.H. (1971): “Displacement of Auditors when Clients go Public", Journal of Accountancy, June, pp. 55-58.

CHOW, C. W. (1982): “The demand for external auditing: Size, debt and ownership influences". The Accounting Review, Abril, pp. 272-291.

CHOW, W. C., AND RICE, S. J. (1982): "Qualified audit opinions and auditor switching”, The Accounting Review, Vol. 57, No. 2, pp. 326-335

CITRON, D.B. AND MANALIS, G. (2001): "The International audit firms as new entrants to the statutory audit market: an empirical analysis of auditor selection in Greece, 1993-1997", European Accounting Review, Vol. 10(3), pp. 439-459.

COLBERT, G. AND MURRAY, D. (1998): “The association between auditor quality and auditor size: An analysis of small CPA firms, Journal of Accounting, Auditing and Finance, Vol. 13(2), pp. 135-150.

COPLEY, P. A. AND DOUTHETT, E. B. (2002): “The association between auditor choice, ownership retained, and earnings disclosure by firms making initial public offerings", Contemporary Accounting Research, 19(1), 49-75.

CORONA ROMERO, E.; GARCÍA BENAU, M.A.; RUÍZ BARBADILLO, E. AND VICO MARTÍNEZ, A. (1995): “The Audit Market in Spain. An Analysis of the Top 250 Non-Financial Companies", Paper presented at the European Accounting Congress, Birmingham.

CRASWELL, A. T. (1988): "The association between qualified opinions and auditor switches", Accounting and Business Research, Vol. 19, No. 73, pp. 23-31.

CRASWELL, A. AND TAYLOR, S. (1991): “The market structure of auditing in Australia: The Role of industry specialization, Research in Accounting Regulation, Vol. 5, pp. 55-77.

CRASWELL, A. T.; FRANCIS, J.R. AND TAYLOR S. L. (1995): “Auditor Brand Name Reputations and Industry Specializations", Journal of Accounting and Economics, pp. 297-322.

CULVENOR, J. AND GODFREY, J. M. (2000): “The derived demand for specialist auditor services", 23th Annual Congress of the European Accounting Association, Munich Germany.

DEANGELO, L. (1981): “Auditor Size and Audit Quality”, Journal of Accounting \& Economics, 3, pp. 183-199.

DE ANGELO, L. E. (1982): “Mandated Successful Efforts and Auditor Choice”, Journal of Accounting and Economics, No. 4, pp. 171-203.

DEBERG, C.; KAPLAN, S. AND PANY, K. (1991): “An examination of some relationships between non-audit services and auditor change, Accounting Horizons, Vol. 5(1), pp. 7-28. 
DEFOND, E. M. (1992): “The Association Between Change in Client Firm Agency Costs and Auditor Switching”, Auditing: A Journal of Practice \& Theory, Vol. 11, No. 1, p. 16-31.

DEFOND, M. L. AND JIAMBALVO, J. (1993): "Factors related to Auditor-client Disagreements over IncomeIncreasing Accounting Methods", Contemporary Accounting Research, 9, pp. 414-431.

DEFOND, M. L. AND SUBRAMANYAM, K. R. (1998): “Auditor Changes and Discretionary Accruals”, Journal of accounting and Economics, 25, pp. 35-67.

DEFOND, M. L.; RAGHUNANDAN, K. AND SUBRAMANYAM, K. R. (2002): “Do non-audit service fees impair auditor independence? Evidence from going concern audit opinions," Journal of Accounting Research, 40, pp. 1.247-1.274.

DHALIWAL, D.; SCHATZBERG, J. AND TROMBLEY, M. (1993): “An Analysis of the Economic Factors Related to Auditor-Client Disagreements Preceding Auditor Changes", Auditing: A Journal of Practice and Theory, Vol. 12, No.2, pp. 22-33.

DOPUCH, N. (1984): "The demand for quality-differentiated audit services in an agency cost setting: An empirical investigation: Discussion, Auditing Research Symposium, University Urbana, pp. 253-263.

DYE, R. A. (1991): “Informationally motivated auditor replacement”, Journal of accounting and Economics, Vol. 14, pp. 374-394.

EICHENSEHER, J. AND SHIELD, D. (1986): “The Correlates of CPA-Firms Change for Publicly Held Corporation, Auditing Journal of Practice and Theory, primavera, pp. 23-32.

EICHENSEHER, J.; HAGIGI, M. AND SHIELDS, D. (1989): “Market reaction to auditor changes by OTC companies, Auditing: A Journal of Practice and Theory, Vol. 9(1), pp. 29-40.

EISENBERG, T. AND MACEY, J.R. (2003): “Was Arthur Andersen Different” An Empirical Examination of Major Accounting Firm Audits of Large Clients", Journal of Empirical Legal Studies, 1(2), pp. 263-300.

FARGHER, N.; TAYLOR, M. AND SIMON, D. (2001): The demand for auditor reputation across international markets for audit services, The International Journal of Accounting, Vol. 36(4), pp. 407-421.

FIRTH, M. (1997): “The provision of non-audit services by accounting firms to their audit Clients, Contemporary Accounting Research, Vol. 14(2), pp. 1-21.

FIRTH, M. (1999): “Company takeovers and the auditor choice decision”, Journal of International Accounting, Auditing \& Taxation, 8(2), pp. 197-214.

FIRTH, M. (2002): “Auditor-Provided Consultancy Services and their Associations with Audit Fees and Audit Opinions", Journal of Business Finance and Accounting, 29, pp. 661-693.

FIRTH, M. AND SMITH, A. (1992): "Selection of auditor firms by companies in new issue market", Applied Economics, 24, pp. 247-255.

FRANCIS, J. (1984): “The Effect of Audit Firm Size on Audit Prices, a Study of the Australian Market”, Journal of Accounting and Economics, Vol. 6 January, p. 133-151.

FRANCIS, J. (2004): “What do we know about audit quality?”, British Accounting Review, Vol. 36(4), pp. 345-368.

FRANCIS, J. AND KRISHNAN, J. (1999): “Accounting Accruals and Auditor Reporting Conservatism”, Contemporary Accounting Research, Vol. 16, pp. 135-165.

FRANCIS, J. AND WILSON, E. (1988): “Auditor Changes: A Test of Theories Relating to Agency Cost and Auditor Differentiation”, The Accounting Review, Vol. 63, No. 4, pp. 663-682.

FRANCIS, J.; RICHELT, K. AND WANG, D. (2005): “The pricing of national and city-specific reputations for industry expertise in the U.S. audit market", The Accounting Review, 80(1), pp. 113-136.

GARCÍA-BENAU, M. A.; RUIZ BARBADILLO, E. AND VICO MARTÍNEZ, A. (1998): Análisis de la estructura del mercado de servicios de auditoría en España. VI Premio de investigación Contable "José María Fernández Pirla”. ICAC, Ministerio Economía y Hacienda, Madrid.

GARCÍA-BENAU, M. A.; RUIZ BARBADILLO, E. AND VICO MARTÍNEZ, A. (2000): "Factores que condicionan la elección y el cambio de auditor en la empresa española”, Revista de Contabilidad, vol. 3, No. 6, pp. 49-80.

GARCÍA-BENAU, M. A.; GARRIDO, P.; VICO, A.; MOIZER, P. AND HUMPREY, C. (1999): "La calidad del servicio de auditoría: los auditores vistos por sus clientes”, Revista Española de Financiación y Contabilidad, Vol. 28, No. 102, pp. $1005-1042$ 
GARCÍA-BENAU, M. A.; MOIZER, P.; HUMPHREY, C. AND VICO MARTINEZ, A. (2004): "The Corporate Image of auditors in a developing audit market within the EU: The case of Spain", European Accounting Review, Vol. 13(3), pp. 561-582.

HASKINS, M. AND WILLIAMS, D. (1990): “A contingent model of intra-Big Eight auditor changes", Auditing: A Journal of Practice and Theory, Vol. 9, No. 3, pp. 55-74.

HEALY, P.; AND LYS, T. (1986): "Auditor Changes Following Big Eight Takeovers of Non-Big Eight Audit Firms", Journal of Accounting and Public Policy, Winter, pp. 251-265

HOGAN, C. E. AND JETER, D. C. (1999): “Industry Specialization by Auditors”, Auditing: A Journal of Practice \& Theory, Vol. 18, No. 1, pp. 1-17.

IRELAND, J. AND LENNOX, C. (2002): “The large audit firm fee Premium: A case of selectivity bias?", Journal of Accounting, Auditing and Finance, Vol. 17(1), pp. 73-91.

JENSEN, M. C. AND MECKLING, H. (1976): "Theory of the firm: Managerial Behavior, Agency Costs and Ownership Structure", Journal of Financial Economics, October, pp. 305-360.

JOHNSON, W. AND LYS, T. (1990): “The Market for Audit Services-Evidence from Voluntary Auditor Changes”, Journal of Accountancy and Economics, p. 281-308.

JONES, F.L. AND RAGHUNANDAN, K. (1998): “Client risk and recent changes in the market for audit services”, Journal of Accounting and Public Policy, 17(2), pp. 169-181.

JOVELL, A. J. (1962): Análisis de regresión logística, Centro de Investigaciones Sociológicas, Universidad de Barcelona.

KINNEY, W.; AND MCDANIEL, L. (1989): “Characteristics of Firms Correcting Previously Reported Quarterly Earnings", Journal of Accounting and Economics, February, p. 72-93.

KLUGER, B. AND SHIELDS, D. (1989): "Auditor Changes, Information Quality and Bankruptcy Prediction", Managerial and Decision Economics, 10, pp. 275-282.

KLUGER, B. AND SHIELDS, D. (1991): “Managerial Moral Hazard and Auditor Changes", Critical Perspectives on Accounting, No. 3, p. 255-272.

KNAPP, M. (1991): "Factors that audit committee members use surrogates for audit quality". Auditing: A Journal of Practice \& Theory, Vol. 10, No. 1.

KNAPP, M. AND ELIKAI, F. (1988): “Auditor changes: A note on the policy implications of recent analytical and empirical research, Journal of Accounting, Auditing and Finance, Vol. 3(1), pp. 78-86.

KNECHEL, W.; NIEMI, L. AND SUNDGREN, S. (2008): “Determinants of Auditor Choice: Evidence from a Small Client Market", International Journal of Auditing, 12, pp. 65-88.

KRISHNAMURTHY, S.; ZHOW, J. AND ZHOW, N. (2002): “Auditor Reputation, Auditor Independence, and the Stock Market Reaction to Andersen's Clients", SSRN Working Paper.

KRISHNAN, J. (1994): “Auditor switching and conservatism”, The Accounting Review, Vol. 69, No. 1, January, pp. 200-215.

KRISHNAN, J. AND STEPHENS, R. G. (1995): “Evidence on opinion shopping from audit opinion conservatism”, Journal of Accounting and Public Policy, No. 14, pp. 179-201.

KRISHNAN, J. AND KRISHNAN, J. (1996): “The role of economic trade-offs in the audit opinion decision: An empirical analysis", Journal of accounting, Auditing and Finance, No. 11, pp. 565-586.

KRISHNAN, J.; KRISHNAN, J. AND STEPHENS, R. (1996): "The simultaneous relation between auditor switching and audit opinion: An empirical analysis, Accounting and Business Research, Vol. 26(3), pp. 224-236.

LANDSMAN, W.R.; NELSON, K.K. AND ROUNTREE, B. (2008): “Auditor switches in the pre and post-Enron eras: risk or realignment?", Accounting Review, forthcoming.

LENNOX, C. (2000): "Do companies successfully engage in opinion-shopping? Evidence from the UK", Journal of Accounting and Economics, Vol. 29, pp. 321-337.

MAGEE, R. P. AND TSENG, M. (1990): "Audit pricing and independence", The Accounting and Business Research, No. 26, pp. 224-236

MCCONNELL, D. K. (1984): "Auditor Changes and Related Disagreements", Auditing: A Journal of Practice \& Theory, 3(2), pp. 44-56. 
MENON, K. AND WILLIAMS, D. (1991): “Auditor Credibility and Initial Public Offerings”, The Accounting Review, No. 2, p. 313.

MENON, K. AND WILLIAMS, D. (2001): “Long-term in Audit Fees”, Auditing: A Journal of Practice and Theory, vol. 20, no. 1 , pp. 115-130.

MOIZER, P. (1997): “Auditor reputation: The international empirical evidence”, International Journal of Auditing, Vol. 1(1), pp. 61-74.

MOIZER, P.; GARCIA BENAU, M. A.; HUMPHREY, C. AND VICO, A. (1998): "Finding the Ideal Auditor: The Images of Audit Firms held by Spanish Financial Directors", Accounting Auditing and Accountability Journal

MONTERREY, J. AND SÁNCHEZ A. (2008): “Gobierno corporativo, Conflictos de Agencia, y Elección de Auditor”, Revista Española de Financiación y Contabilidad, Vol. XXXVII, No. 137, pp. 113-156.

NICHOLS, D. AND SMITH, D. (1983): “Auditor credibility and auditor changes”, Journal of Accounting Research, Vol. 21(2), pp. 534-544.

PALMROSE, Z. (1984): "The demand for quality-differentiated audit services in an agency cost setting: An Empirical Investigation", Auditing Research Symposium (University of Illinois), pp. 229-252.

PALMROSE, Z. (1986): “Audit fees and auditor size: Further evidence”, Journal of Accounting Research, Vol. 24, No. 1, pp. 97-110.

PIOT CH. (2001): “Agency Costs and Audit Quality: Evidence from France”, The European Accounting Review, vol. 10(3), pp. 461-499.

PITTMAN, J. AND FORTIN, S. (2004): “Auditor choice and the cost of debt capital for newly public firms", Journal of Accounting and Economics, 37, pp. 113-136.

ROBERTSON, R. (2002): “How four may become three, or seven two”, Australian Financial Review, 4 July $2002,20$.

RUIZ BARBADILLO, E. AND GÓMEZ AGUILAR, N. (2003): "Evidencia empírica sobre inductores del cambio de auditor: Especial referencia a la situación financiera de la empresa”, Revista de Contabilidad, Vol. 6, no. 12 juliodiciembre 2003, pp. 139-167.

SÁNCHEZ SEGURA, A. (2003): “Salvedades y cambio de auditor”, Revista Española de Financiación y Contabilidad, Vol. XXXII, No. 119, pp. 983-1012.

SCHWARTZ, K. (1982): “Accounting Changes by Corporations Facing Possible Insolvency”, Journal of Accounting, Auditing and Finance, Fall pp. 32-43

SCHWARTZ, K. B. AND MENON, K. (1985): “Auditor Switches by failing firms”, The Accounting Review, Vol. 60, No.2, pp. 248-261.

SCHWARTZ, K. AND SO0, B. (1996): "The Association between Auditor Changes and Reporting Lags", Contemporary Accounting Research, 1, 353-70.

SHAMHARIR A.; BEATTIE V. A. AND GOODACRE A. (2008): "Audit Market Structure, Fees and Choice following the Andersen Break-up: Evidence from the UK", Working Paper series available at http://ssrn.com/abstract=1096464 (November, 2008).

SHLEIFER, A. AND VISHNY, R. (1986): “Large shareholders and corporate control, Journal of Political Economy, vol. 94, pp. 461-488.

SIMON, D. (1985): “The audit services market: Additional empirical evidence, Auditing: A Journal of Practice and Theory, Vol. 5(1), pp. 71-78.

SIMON, D. AND FRANCIS, J. (1988): "The Effects of Auditor Changes on Audit Fees: Tests of Price Cutting and Price Recovery", The Accounting Review, April, p. 255-269.

SIMUNIC, D. (1980): “The Pricing of Audit Services: Theory and Evidence”, Journal of Accounting Research, Vol. 18. n. 1, pp. 161-190.

SIMUNIC, D. A. AND STEIN, M. (1987): "Product Differentiation in Auditing: A Study of Auditor Choice in the Market for New Issues”, Canadian Certified General Accounts Research Foundation, Monograph 13.

SIMUNIC, D. AND STEIN, M. (1995): "Research into markets for auditing services, Working paper presented on The advance Course in Audit Research, October, Maastricht Netherlands.

SMITH, D. B. (1986): “Auditor 'subject to' opinions, disclaimers, and auditor changes”, Auditing: A Journal of Practice \& Theory, Vol. 6, No. 1, pp. 95-108 
SMITH, J. (2005): “Auditors' liability and audit quality”, Draft Regulatory Impact Assessment, Company Law Reform Bill, pp. 1-13.

SUCHER, P.; MOIZER, P. AND ZAROVA, M. (1998): "The Images of the Big Six audit firms in the Czech Republic", paper presented at the XXI Congress of the European Accounting Association.

SUTTON, S. AND LAMPE, J. (1990): "Formulating a Process Measurement System for Audit Quality", In Proceedings of the 1990 University of South California Audit Judyment Symposium.

SWEENEY, A. (1994): “Debt-covenant violations and managers' accounting responses", Journal of Accounting and Economics, 17, pp. 281-308.

TAYLOR, M.H. (1997): “The market for audit services in Japan, Pacific”, Accounting Review, Volume 9, pp. 59-74.

TAYLOR, M.H. AND SIMON, D.T. (2003): "Audit markets in emerging economies: evidence from Nigeria", Research in Accounting in Emerging Economies, Volume 5, pp. 165-175.

TEOH, S. AND WONG, T. (1993): "Perceived auditor quality and the earnings response coefficient, The Accounting Review, Vol. 68(2), pp. 346-366.

TITMAN, S. AND TRUEMAN, B. (1986): "Information quality and the evaluation of new issues", Journal of Accounting \& Economics, 8, pp. 159-172

TOMCZYK, S. (1996): “Auditor reputation and initial public offerings by foreign companies", Journal of International Accounting, Auditing \& Taxation, 5(2), pp. 249-263.

TURPEN, R. (1990): “Differential Pricing on Auditors' Initial Engagements: Further Evidence”, Auditing: A Journal of Practice \& Theory, Vol. 4, No. 1, p. 60-76.

VAFEAS, N. (1999): "Board meeting frequency and firm performance", Journal of Financial Economics, 53, pp. 113142.

VIVES, X. (1990): “Conceptos y Evidencia Empírica”, Recogido en Concentración Empresarial y Competitividad, Dirección y Coordinación Vives, X, y Gual, J. pp. 23-52.

WALLACE, W. (1998): "Changes in European and Australian companies when they choose a Big Five auditor?", European Management Journal, vol. 16, no. 6, pp. 653-659.

WATTS, R. AND ZIMMERMAN, J. (1983): "Agency problems, auditing, and the theory of the firm: Some evidence", Journal of Law and Economics, Vol. 26(3), pp. 613-633.

WATTS, R. AND ZIMMERMAN, J. (1986): “Positive Accounting Theory”. Prentice-Hall Englewood Cliffs, New Jersey.

WEETS, V. (1999): “Who will be the new auditor?” Working paper, University of Ghent.

WHISENANT, J. AND SANKARAGURUSWAMY, S. (2000): “Evidence on the auditor and client relationship: What can be learned from reasons reported by managers for changing auditors?" Working paper, SSRN.

WILSON, E.; KHURANA, Y. AND ALBRECHT, W. (1995): “Additional Evidence on Auditor Changes: The Effects on Client Financial Condition", Advances in Accounting, Vol. 13, p. 153-168.

WILSON, T. AND GRIMLUND, R. (1990): “An examination of the importance of an auditor's reputation, Auditing: A Journal of Practice and Theory, Vol. 9(2), pp. 43-59.

WILLIAMS, D. D. (1988): “The Potential Determinants of Auditor Change", Journal of Business, Finance and Accounting, 15(2), pp. 243-261.

WOO, E. AND KOH, H. (2001): "Factors associated with auditor changes: A Singapore study", Accounting and Business Research, Vol. 31(2), pp. 133-144.

ZEFF S. AND FOSSUM, R. (1967): "An analysis of Large Audit Clients", The Accounting Review, Vol. 42, No. 2. April, pp. 298-320. 